\title{
GSTRUTURA E ORGANIZAÇÃO DO PODER EXECUTIVO
}

\section{Dirotoria do [asudes \\ - Posquisas \\ da E N A P}

laborado a partir dos relatórios finais da pesquisa Estrutura e Organização do Poder Fxecutivo Frente à Opção pelo Sistema de Governo, encomendada pela ENAP ao Centro de Estudos de Cultura Contemporânea (CEDEC), dentro do projeto ENAP/PNUD BRA 90/017, este trabalho compõc-se de dois volumes. $O$ primeiro apresenta quatro estudos do sistema de governo e das relaçōes entre administração pública c o sistema político na Alemanha, França, Grä-Bretanha c Itália. O segundo volume analisa o caso brasileiro, a partir de três aspectos: profissionalização do serviço público, modernização do Estado $e$ as rclaçôes entre administração c política, sintetizando as principais hipóteses, diagnósticos e diretrizes de uma reforma administrativa.

Os dois volumes basciam-se numa ampla pesquisa $c$ análise bibliográfica estrangeira e nacional e num conjunto de 51 entrevistas realizadas com quadros superiores da administração federal, assessores parlamentares, acadêmicos e consultores da área.

Este trabalho se propõe a pesquisar, aprofundar e sistematizar os estudos e análises sobre a situação atual da administração pública brasileira, scus problemas c altemativas de soluçōes, assim como a relação com o sistema político brasilciro.

As principais conclusōes deste trabalho são:

1) O sistema de governo presidencialista multipartidário, tal como se encontra estruturado no Brasil, contribui decisivamente para a desorganização c o mau funcionamento da administração pública federal;

2) O Executivo, especialmente o scu órgāo central, a Presidência da República, não está capacitado, política e administrativamentc, para dirigir, coordenar e controlar a administração pública federal; 
3) Em comparação com o processo decisório nos sistemas parlamentaristas estudados neste trabalho, o plancjamento, a tomada de decisōes e mesmo a coordenação das atividades do İxecutivo no Brasil apresentam um grau clcvado de improvisaçāo e aleatoriedade;

\{) Através de um breve histórico da administração pública brasilei$\mathrm{ra}$, o segundo volume mostra que o engessamento e a burocratizaçāo da máquina pública levaram, desde a década de 50, ao desenvolvimento de estruturas paralelas, quer para remunerar núcleos de competência, quer para flexibilizar a gestão do Poder Executivo visando a superaçāo destes problemas;

5) E, finalmente, a falta de profissionalização do servidor e do serviço público. A precariedade dos dados disponíveis sobre o funcionalismo, a falta de políticas consistentes na área de recursos humanos, principalmente em relaçāo às carreiras e à remuneração dos servidores públicos, e um sistema de mérito ineficiente c ineficà sāo algumas das conclusōes que este trabalho demonstra em comparaçāo com os países analisados.
Estrutura c Organizaçāo do Poder Fxecutivo. Regis de Castro Andrade c Iuciana Jaccoud (organizadores) Brasilia, FNAP, 1994, 2v.

Rescnha claborada por técnicos da Dirctoria de Isstudos c Pesquisas da ENAP. 